\title{
REMOVAL OF As(III) FROM WATER USING A NOVEL ORANGE PEEL BIOPOLYMER BASED MAGNETIC NANOCOMPOSITES
}

\author{
NGHIA T. BUI ${ }^{1}$, CAN D. PHAN ${ }^{1}$, HUY Q. NGUYEN ${ }^{1}$, SON V. LE $^{2}$, VAN T. T. TRAN ${ }^{1}$, \\ NGOC T. T. TRAN ${ }^{3}$ \\ ${ }^{1}$ Institute of Environmental Science, Engineering and Management, Industrial University of Ho Chi Minh \\ City, Ho Chi Minh City. \\ ${ }^{2}$ Faculty of Environment - Natural Resources and Climate Change, Ho Chi Minh City University of Food \\ Industry (HUFI), Ho Chi Minh City. \\ ${ }^{3}$ Ho Chi Minh City University of Natural Resources and Environment, Ho Chi Minh City. \\ btnghia109@gmail.com
}

\begin{abstract}
Arsenic pollution in groundwater is of high concern due to its impact to environment and human health. Numerous methods have been used to treat arsenic pollution. In this work, a practical application of biopolymer-based magnetic nanocomposites as a novel adsorbent for the arsenic pollutant was demonstrated. Magnetic nanocomposites were produced by incorporating cobalt superparamagnetic $\left(\mathrm{CoFe}_{2} \mathrm{O}_{4}\right)$ nanoparticles into the biopolymer matrix which was extracted from orange peel. In which, the superparamagnetic nanoparticles were prepared by co-precipitation approach and the nanocomposites formation was carried out with the support of magnetic agitation. Various characterizations including Fourier transform infrared spectroscopy (FT-IR), X-ray powder diffraction (XRD), Scanning electron microscopy (SEM), and Vibrating sample magnetometry (VSM) were carried out to investigate the property of the obtained biopolymer magnetic nanocomposites. The materials was used as adsorbent, then applied to remove arsenic trioxide in the solution. The result indicated that $99.2 \%$ of arsenic trioxide $(1.0 \mathrm{~g} / \mathrm{L}$ feed concentration, $1.0 \mathrm{~g} / \mathrm{L}$ dose of the material) could be removed by the adsorbent. In addition, the nanocomposites after treatment could be facilely separated from the aqueous mixture by simple magnetic decantation due to its superparamagnetism, making it easy to completely isolate them from water and exhibiting good reusability.

Keywords. nanocomposites, magnetic, orange peel, biopolymer, superparamagnetism, As (III), reusability.
\end{abstract}

\section{INTRODUCTION}

Arsenic (As), one of the common constituents of the earth's crust, is a contaminant in groundwater source. Groundwater arsenic pollution has been reported from numerous countries all over the world. A high concentration of arsenic is a big concern for drinking water and food safety. Long-term exposure to arsenic may cause negative effects on human health, even can lead to cancers [1]. Therefore, removal of arsenic from water is of high importance. Many different technologies such as precipitation, adsorption, ion exchange, membrane filtration, etc. have been used for arsenic removal from aqueous solution [2, 3]. Each method has its own advantages and disadvantages [4]. Among these methods, adsorption is one of the most efficient approaches which is cost-effective to remove arsenite(III) in groundwater. Various types of low cost adsorbent have been applied including oxides, soils and constituents, phosphates, agricultural products, industrial by-products as well as biosorbent [4]. Recently, biopolymer, which is biodegradable, hence environment-friendly, has demonstrated as a potential adsorbent to remove heavy metals in aqueous solution [5]. However, the separation of adsorbent from post-treatment water is still a drawback which inhibits its practical application. To overcome this challenge, polymer can be combined with magnetic nanoparticles, which can be easily isolated from water by applying a magnetic field [6]. Moreover, the adsorption capacity of such nanocomposites can be enhanced greatly since magnetic nanoparticles are also well-known as superior adsorbents [7]. In this work, we attempt to use waste orange peel as biopolymer source for preparing polymer-based magnetic nanocomposite as an adsorbent to remove As(III) in groundwater with enhanced collection ability. 


\section{MATERIALS AND METHODS}

Materials: the reagents including cobalt (II) chloride $\left(\mathrm{CoCl}_{2} \cdot 6 \mathrm{H}_{2} \mathrm{O}, 99 \%\right)$; iron (II) chloride $\left(\mathrm{FeCl}_{2} .4 \mathrm{H}_{2} \mathrm{O}\right.$, $98 \%)$; sodium hydroxide $(\mathrm{NaOH}, 96 \%)$; n-hexane $(95 \%)$; ethanol $\left(\mathrm{C}_{2} \mathrm{H}_{5} \mathrm{OH}, 96^{\circ}\right)$; ammonium hydroxide $\left(\mathrm{NH}_{4} \mathrm{OH}, 25-28 \%\right)$; arsenic trioxide $\left(\mathrm{As}_{2} \mathrm{O}_{3}, 99 \%\right)$; chemical analysis filter paper (Newstar 101, filter hole diameter 20-25 $\mu \mathrm{m}$ ) were supplied from China. While sodium dodecyl sulfate (SDS, $>85 \%$ ) was provided by Merck. All the reagents were used as received without any further purification. Orange peel was obtained from Go Vap market, HCM city, Vietnam.

\subsection{Biopolymer isolation}

The orange peel biopolymer was isolated following a modified procedure from previous publications [8, 9]. Firstly, $3.0 \mathrm{~g}$ of dried orange peel pulp was washed, chopped and blanched in hot water $\left(60^{\circ} \mathrm{C}\right)$. After adjusting $\mathrm{pH}$ to 2 using $0.1 \mathrm{~N} \mathrm{HCl}$ solution, the mixture was boiled for 180 minutes to remove enzymes. The mixture was then cooled to room temperature and adjusted to $\mathrm{pH} 7.0$ by $0.01 \mathrm{~N} \mathrm{NaOH}$ solution. The first filtration was performed to get the filtrate and the precipitation of biopolymer was done by ethanol $96^{\circ}$ overnight. The second filtration was performed to obtain biopolymer, then the biopolymer was washed several times with $96^{\circ}$ ethanol. Finally, the biopolymer was dried at $60^{\circ} \mathrm{C}$ prior to storage.

Biopolymer yield was calculated as follows:

\subsection{Synthesis and hydroxylation of magnetic nanoparticles}

$$
\text { Biopolymer }(\%)=\frac{\text { Weight }(g) \text { of dried biopolymer }}{\text { Weight }(g) \text { of dried orange peel }} \times 100 \%
$$

The preparation of magnetic nanoparticles was followed a reported procedures $[9,10]$. $\mathrm{CoFe}_{2} \mathrm{O}_{4}$ magnetic nanoparticles were obtained by coprecipitation using sodium dodecyl sulfate (SDS) as surfactant. Firstly, $250 \mathrm{ml}$ aqueous solution of SDS $(9.35 \mathrm{~g} ; 27.75 \mathrm{mmol})$ was rapidly added into $250 \mathrm{ml}$ aqueous solution of a mixture containing $\mathrm{CoCl}_{2} .6 \mathrm{H}_{2} \mathrm{O}(1.2 \mathrm{~g} ; 5.00 \mathrm{mmol})$ and $\mathrm{FeCl}_{2} .4 \mathrm{H}_{2} \mathrm{O}(2.0 \mathrm{~g} ; 10.00 \mathrm{mmol})$. The solution was then heated to $\left(70 \pm 5{ }^{\circ} \mathrm{C}\right)$ under stirring and maintained at these conditions for 30 mins. Successively, $500 \mathrm{ml}$ of $\mathrm{NaOH} 0.75 \mathrm{M}$ was slowly poured into the reaction vessel and the solution was vigorously stirred in 5 hours. The fabricated magnetic nanoparticles were collected by a strong magnet, then washed with water, ethanol and n-hexane to remove the excess of surfactant and finally were left for drying overnight at ambient conditions $[9,10]$. Then, the hydroxylation of obtained $\mathrm{CoFe}_{2} \mathrm{O}_{4}$ magnetic nanoparticles was carrying out by firstly dispersing them in $350 \mathrm{ml}$ mixture of ethanol and water $(1: 1, \mathrm{vol} / \mathrm{vol})$ under sonication for $30 \mathrm{mins}$. Then, $35 \mathrm{ml}$ ammonium hydroxide was added and the suspension was vigorously stirred at $55-65^{\circ} \mathrm{C}$ in 24 hours. Hydroxylated magnetic nanoparticles were recovered by a strong magnet, washed with excess of water, ethanol and left for drying overnight in air $[9,10]$.

2.3 Synthesis of nanocomposites based on the hydroxylated magnetic nanoparticles and orange peel biopolymer

The hydroxylated magnetic nanoparticles were added to $1.0 \mathrm{wt} \%$ biopolymer solution in a $500 \mathrm{~mL}$ beaker, weight ratio of hydroxylated magnetic nanoparticles/ biopolymer was $1 / 5(\mathrm{~g} / \mathrm{g})$. The mixture was stirred and kept stable at $90{ }^{\circ} \mathrm{C}$ in 30 minutes. The formed nanocomposites were taken out using a strong magnet, washed with excess of water, ethanol, $n$-hexane and left for drying in air.

\subsection{Characterization}

The crystalline structure of the synthesized materials was investigated by X-ray diffraction (XRD) which patterns were recorded by a D8-Advance from Bruker using monochromatic $\mathrm{Cu} \mathrm{K}_{\alpha}$ radiation. The $2 \theta$ scanning ranges from $10-80^{\circ}$ at a scanning rate of $2.25^{\circ} / \mathrm{min}$. The presence of biopolymer in nanocomposite composition was studied by Fourier transform infrared (FT-IR) spectrometer (TENSOR 27- Bruker, Germany) in the wavenumber range of $400-4000 \mathrm{~cm}^{-1}$. Scanning Electron Microscopy (SEM) (S-4800) was used to observe the morphology of the nanomaterials while vibrating sample magnetometer (VSM) was applied to assess magnetic properties via hystereris loop.

\subsection{Removal of As(III) in aqueous solution via adsorption}

In a typical experiment, $100 \mathrm{ml}$ aqueous solution containing $0.1 \mathrm{~g} / \mathrm{L} \mathrm{As}(\mathrm{III})$ was added into a beaker. Then, a certain amount of adsorbent materials (either orange peel biopolymer or $-\mathrm{OH}$ enriched magnetic nanoparticles or biopolymer based nanocomposites) was added into each beaker. The mixture was agitated at $120 \mathrm{rpm}$ for $5 \mathrm{~h}$ at ambient temperature. Finally, the adsorbent materials were simply collected by applying a magnet. As(III) in the obtained supernatant was precipitated by adjustment $\mathrm{pH} 5$ by $0.1 \mathrm{M} \mathrm{HCl}$, 
the filter residue was dried and weighed to determine the efficiency of the As(III) treatment. Each sample was duplicated and the average result was recorded. The amount of the arsenic adsorbed $(\mathrm{mg})$ per unit mass of adsorbent $(\mathrm{g}), \mathrm{q}_{\mathrm{e}}(\mathrm{mg} / \mathrm{g})$, was obtained by mass balance using following equation:

$$
q_{e}=\frac{C_{i}-C_{e}}{C_{a}}
$$

where $C_{i}$ and $C_{e}$ are initial and equilibrium concentrations of $A s(I I I)(m g / L), C_{a}$ is concentration of adsorbent $(\mathrm{g} / \mathrm{L})$.

Effect of adsorbents: effect of adsorbents on the percentage of As(III) adsorption by biopolymer, $-\mathrm{OH}$ enriched magnetic nanoparticles and nanocomposites were studied in the parameters: adsorbent dose 1.0 $\mathrm{g} / \mathrm{L}$, initial As(III) concentration $1.0 \mathrm{~g} / \mathrm{L}$, contact time $5 \mathrm{~h}, \mathrm{pH}$ 12, agitation speed $120 \mathrm{rpm}$ and volume 100 $\mathrm{mL}$, were kept constant.

Effect of mass ratio of nanocomposites adsorbent to As(III): the effect of the weight ratio on the percentage of As(III) adsorption by nanocomposites adsorbent was studied by varying the adsorbent dose from $0.5 \mathrm{~g} / \mathrm{L}$ to $2.5 \mathrm{~g} / \mathrm{L}$. Other parameters were kept constant, such as the initial As(III) concentration $0.5 \mathrm{~g} / \mathrm{L}$, contact time $5 \mathrm{~h}, \mathrm{pH} 7.0$, agitation speed $120 \mathrm{rpm}$ and volume $100 \mathrm{~mL}$.

Effect of $\mathrm{pH}$ : effect of $\mathrm{pH}$ on the percentage of $\mathrm{As}(\mathrm{III})$ adsorption by the nanocomposites adsorbent was studied in the $\mathrm{pH}$ range of 6 to 10. Other parameters, such as adsorbent dose $0.4 \mathrm{~g} / \mathrm{L}$, initial As(III) concentration $0.1 \mathrm{~g} / \mathrm{L}$, contact time $5 \mathrm{~h}$, agitation speed $120 \mathrm{rpm}$ and volume $100 \mathrm{~mL}$, were kept constant. The $\mathrm{pH}$ of the solution was adjusted by adding $0.1 \mathrm{M} \mathrm{HCl}$ and $0.1 \mathrm{M} \mathrm{NaOH}$. A pH of the solution was determined by using pH Tester, HANNA HI-98107, Romania.

Effect of contact time: the effect of contact time on the percentage of As(III) adsorption by nanocomposites adsorbent was studied at different contact time from 1.0 to $5.0 \mathrm{~h}$. Other parameters were kept constant, such as the adsorbent dose $0.4 \mathrm{~g} / \mathrm{L}$, initial As(III) concentration $0.1 \mathrm{~g} / \mathrm{L}, \mathrm{pH} 6$, agitation speed $120 \mathrm{rpm}$ and volume $100 \mathrm{~mL}$.

Desorption and reusability: desorption experiment was investigated using $0.1 \mathrm{M} \mathrm{NaOH}$. Nanocomposites adsorbent was first loaded with As(III) by mixing $0.04 \mathrm{~g}$ adsorbent with $100 \mathrm{~mL}$ of $0.1 \mathrm{~g} / \mathrm{L} \mathrm{As}$ (III) solution under agitation for $5 \mathrm{~h}$ to reach equilibrium. The resultant suspension was magnetically separated and the remaining As(III) concentration in supernatant was determined. Subsequently, the solid residue was thoroughly washed with copious distilled water and mixed with $20 \mathrm{~mL}$ of $0.1 \mathrm{M} \mathrm{NaOH}$ at room temperature under agitation condition for $6 \mathrm{~h}$. After desorption, the adsorbent was reused for removal As(III) for subsequent times with similar conditions.

Study of removal of As(III) in aqueous solution was performed in Jartest system (OVAN JT60E, Spain).

\section{RESULTS}

\subsection{Orange peel biopolymer isolation}

A fixed amount of $3.0 \mathrm{~g}$ orange peel was used for biopolymer isolation and the process was performed at the mass ratio of solvent/orange peel sample reached 30/1 (wt/wt). According to previous studies [11, 12], it was reported that the enzyme-reduction is not completed at the temperature below $60{ }^{\circ} \mathrm{C}$. Hence, the proper temperature for enzyme reduction was investigated. Except temperature, the biopolymer isolation of orange peel also depends on isolation time, $\mathrm{pH}[13,14]$.
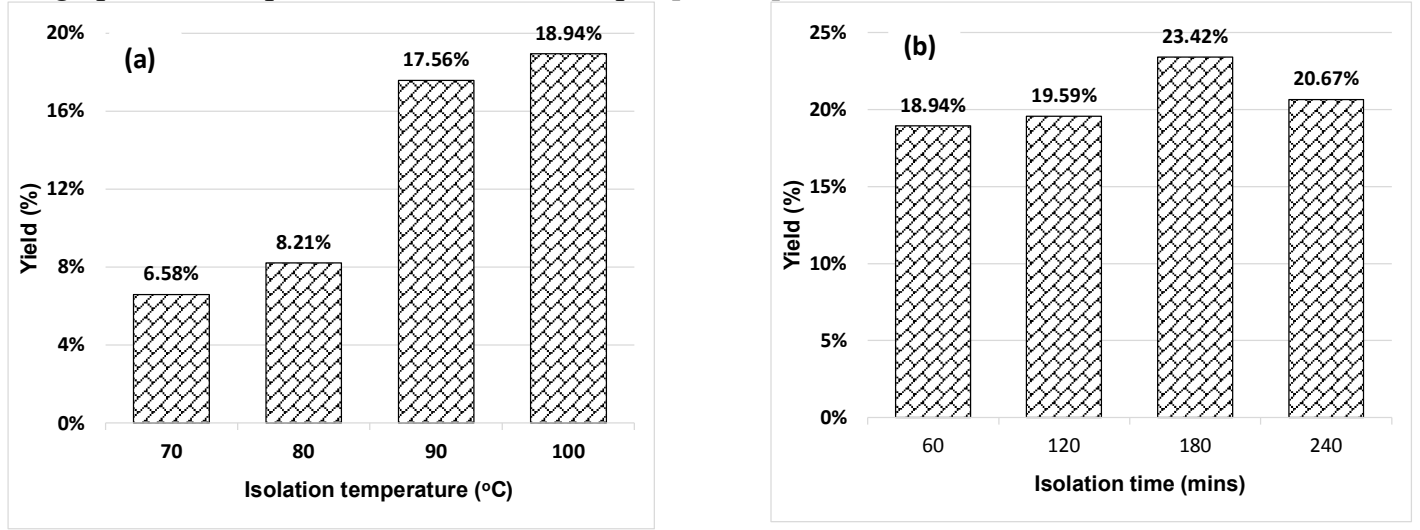


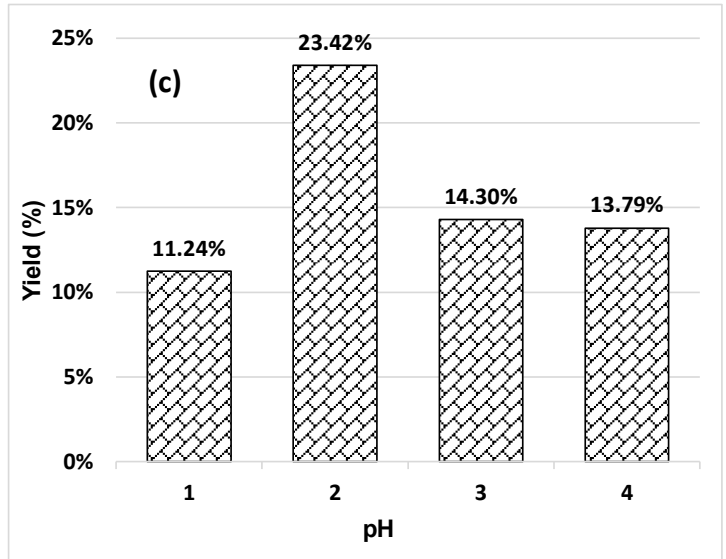

Figure 1. Effect of temperature (a), time (b) and $\mathrm{pH}$ (c) on biopolymer isolation in the following conditions: 1.

Enzyme reduction: $\mathrm{HCl} 0.01 \mathrm{~N} ; 2$. Ratio of solvent to sample: $30 / 1 ; 3$. Weight of orange peel: $3.0 \mathrm{~g}$

The effect of biopolymer isolation conditions show that the maximum amount of biopolymer was obtained when the temperature reached $100{ }^{\circ} \mathrm{C}$, in 180 minutes and $\mathrm{pH} 2$. The effect of temperature was also studied in this work in which the highest biopolymer isolation yield of $18.94 \%$ was achieved at $100{ }^{\circ} \mathrm{C}$ (Figure 1a), this finding was also reported in previous research [13, 14]. Additionally, obtained biopolymer amount depends on the isolation time where $23.42 \%$ was the highest yield when carrying out the isolation for 180 mins and prolong the time lead to the decrease of isolation yield (Figure 1b). Differently, when using $\mathrm{HCl}$ as reducing agent for the enzyme reduction, the yield of biopolymer isolation was lower when either increasing or reducing $\mathrm{pH}$ (Figure 1c). It is assumed that increasing the $\mathrm{pH}$ of the environment leads to the increase in solubility of the biopolymer, hence reduce their collected amount. Moreover, at $\mathrm{pH}$ higher than 2 , diminished acidity cause a decrease in enzyme reducing capability of the environment which weaken the ability to convert the $-\mathrm{COOCH}_{3}$ group with weak polarity into $-\mathrm{COOH}$ group with stronger polarization. As a result, the attained amount of biopolymer also decreased which is consistent with the previous findings $[11,12]$.

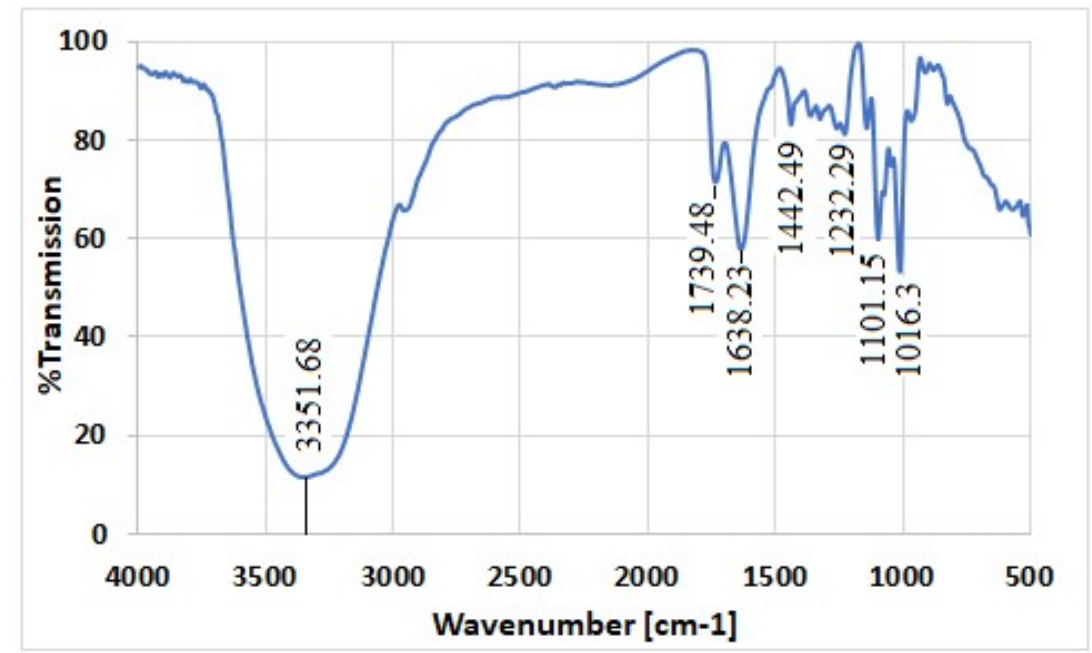

Figure 2. FT - IR spectrum of biopolymer

FT-IR results (Figure 2) show strong vibrational band centered at $3351.68 \mathrm{~cm}^{-1}$ which is typical oscillations for the $-\mathrm{OH}$ group. Further, the peak at $1739.48 \mathrm{~cm}^{-1}$ corresponds to the stretching vibrations of non-ionized $\mathrm{C}=\mathrm{O}$ groups and the bands centered at $1638.23 \mathrm{~cm}^{-1}$ and $1442.49 \mathrm{~cm}^{-1}$ are characteristic for asymmetric and symmetric stretching vibrations of the $\mathrm{COO}^{-}$group indicate low degree of esterification of the obtained 
biopolymer $[15,16]$. Moreover, the peaks at the wavenumber of $1232.29 \mathrm{~cm}^{-1}, 1101.15 \mathrm{~cm}^{-1}$ and 1016.3 $\mathrm{cm}^{-1}$ represent characteristic vibrations of C-O in the C-O-H group of galactomannan $[15,17]$.

\subsection{Characterization of the obtained magnetic nanoparticles and nanocomposites}

The structure of the synthesized $\mathrm{CoFe}_{2} \mathrm{O}_{4}$ magnetic nanoparticles was investigated by X-ray diffraction method (XRD). The results (Figure 3c) show that the diffraction spectrum is completely consistent with the standard data (JCPDS card, No. 22-1086) and totally matches with previous studies on $\mathrm{CoFe}_{2} \mathrm{O}_{4}$ magnetic nanomaterials $[10,18]$. In the XRD results, there were some peaks which represent impurities and amorphous structures. Moreover, it is observed in SEM image (Figure 3b) that the diameter of the $\mathrm{CoFe}_{2} \mathrm{O}_{4}$ magnetic nanoparticles varies in the range of 40-90 nm. The VSM results of $\mathrm{CoFe}_{2} \mathrm{O}_{4}$ nanoparticles and nanocomposites are shown in Figure 3d(I, II). Which exhibited the saturation of $\mathrm{CoFe}_{2} \mathrm{O}_{4}$ particles is 60.66 $\mathrm{emu} / \mathrm{g}$ (magnetic resistance $4937.85 \mathrm{G}$ ) while the saturation of nanocomposites is $54.59 \mathrm{emu} / \mathrm{g}$ (magnetic resistance $4940.06 \mathrm{G}$ ). The materials with a saturation of $60.66 \mathrm{emu} / \mathrm{g}$ together with the particle size in nano range, the obtained nanomaterial is considered to possess superparamagnetic properties and therefore the material disperses well in solution and is easily recovered by external magnetic field when being used in As(III) treatment.

The presence of functional groups within $\mathrm{CoFe}_{2} \mathrm{O}_{4}$ magnetic nanoparticles as well as on their surface was determined by FT-IR spectrum. The result in Figure 3e.I shows the valence absorption band of Fe-O bond via peak centered at the wavenumber $551.54 \mathrm{~cm}^{-1}$. Furthermore, $\mathrm{OH}$ bonds in hydroxyl group on the surface of magnetic nanoparticles were presented by valence oscillation in the vicinity of $3422.06 \mathrm{~cm}^{-1}$ and deformation oscillation at $1639.2 \mathrm{~cm}^{-1}$. FT - IR analysis of nanocomposite (Figure 3e.IV) shows that there is still a peak corresponds to the vibration of $\mathrm{Fe}-\mathrm{O}$ bond at $538.04 \mathrm{~cm}^{-1}$ which is a characteristic oscillation of $\mathrm{CoFe}_{2} \mathrm{O}_{4}$. The strong vibration peak at $3289.96 \mathrm{~cm}^{-1}$ is typical for $-\mathrm{OH}$ group and peaks centered at $1630.52 \mathrm{~cm}^{-1}$ and $1414.53 \mathrm{~cm}^{-1}$ are characteristic asymmetric and symmetric vibrations of $\mathrm{C}=\mathrm{O}$ bonding in COO- group $[15,16]$. It was reported that $[19-25]$, the peaks centered at $1630.52 \mathrm{~cm}^{-1}$ và $1414.53 \mathrm{~cm}^{-1}$ could be attributed to the vibrations of asymmetric and symmetric metal-carboxylate bond (COO-Fe). Further, the difference $(\Delta)$ between $v_{\text {asy }}(\mathrm{COO}-)$ and $v_{\text {sym }}(\mathrm{COO}-)$ absorption band is indicative of the binding character of a carboxylate group with a metal ion. The $\Delta$ value of $\left(1630.52-1414.53=215.99 \mathrm{~cm}^{-}\right.$ ${ }^{1}$ ) can be assigned to the bidentate bridge between $\mathrm{COO}-$ and $\mathrm{Fe}^{2+}, \mathrm{Fe}^{3+}$ ions [24, 26-28]. SEM image of nanocomposites materials is displayed in Figure 3c. According to observation, the surface of the nanocomposites is relatively rough, clustered together.

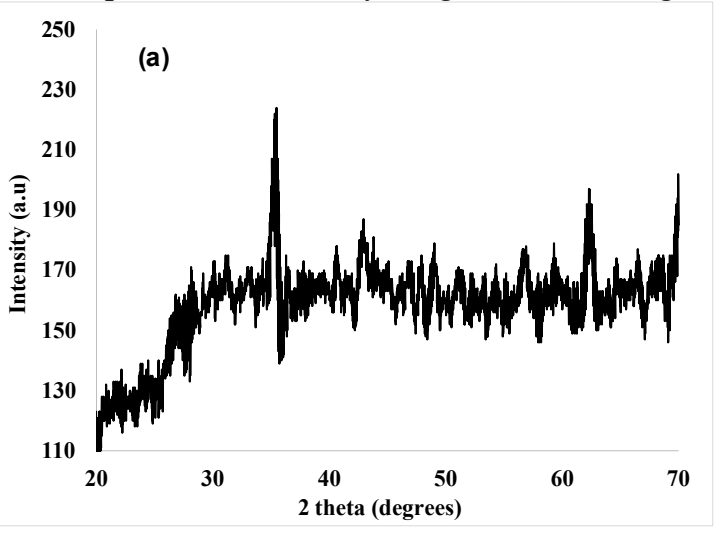

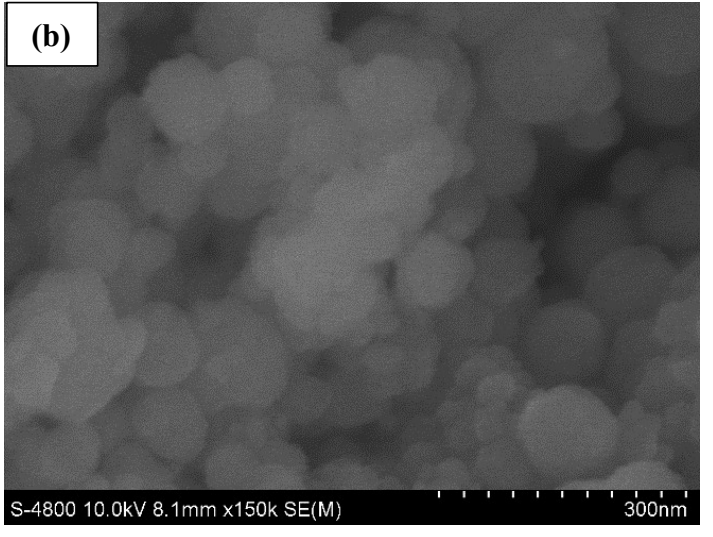



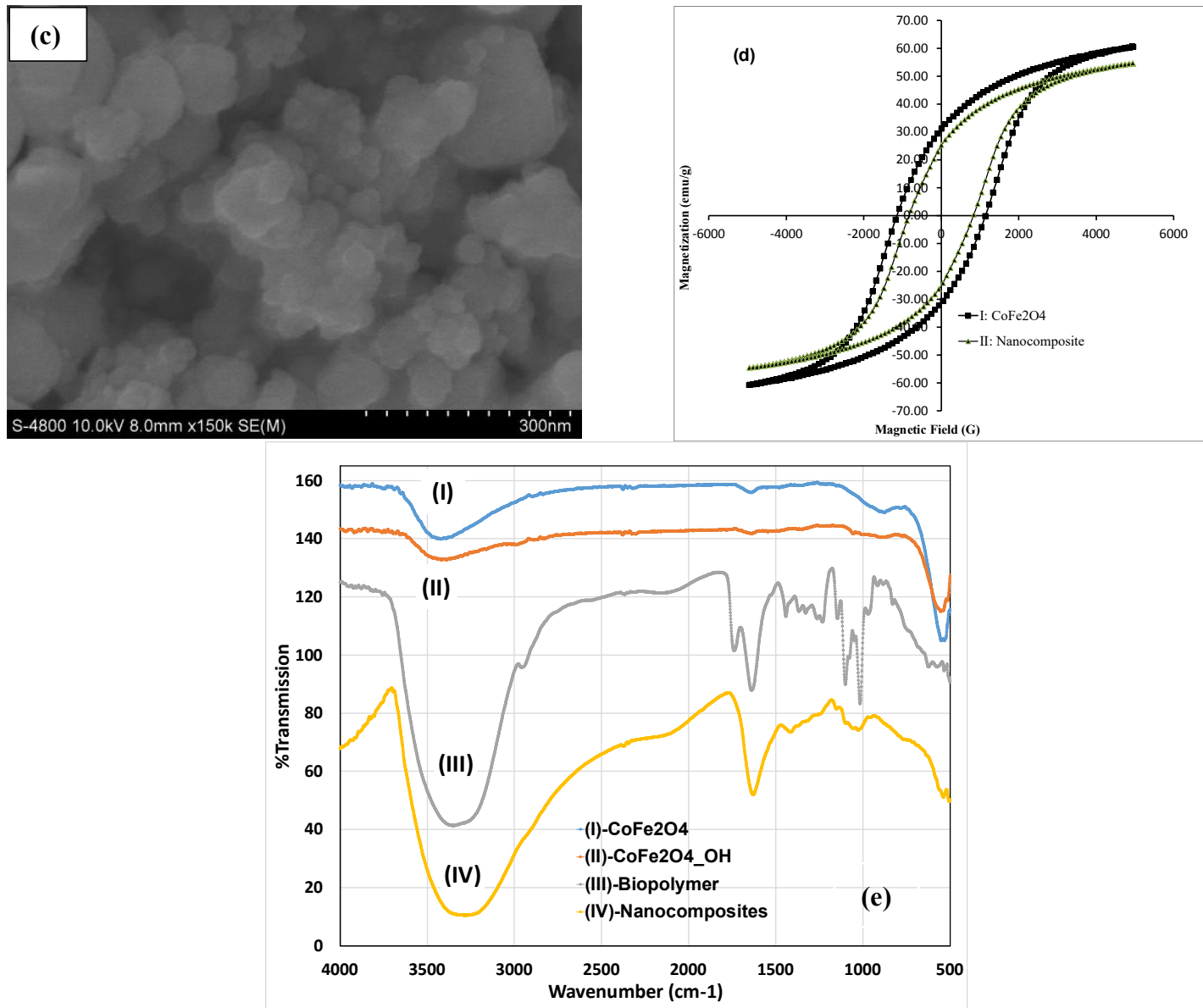

Figure 3. Characterization of magnetic nanoparticles and nanocomposites: (a) XRD results (CuK $\alpha$ - radiation) of

$\mathrm{CoFe}_{2} \mathrm{O}_{4}$; (b) SEM image of $\mathrm{CoFe}_{2} \mathrm{O}_{4}$; (c) SEM image of nanocomposites; (d) Hysteresis curve; (e) FT - IR spectra of adsorbent materials

\section{3 $\quad \mathrm{As}(\mathrm{III})$ treatment efficiency via adsorption}

The efficiency in treating As(III) of various materials was demonstrated in Figure 4a in which the adsorption yield was in the order Nanocomposites > Orange peel biopolymer $>$ magnetic nanoparticles. Even though the magnetic nanoparticles have their own adsorption capability owing to the presence of hydroxyl groups, the ready aggregation of the particles reduces their available adsorption surface, resulting in their lowest adsorption capacity. Meanwhile, it is assumed that the mechanism of As(III) treatment using the polymerbased materials is mainly adsorption in which the As(III) adsorbs onto the polymer materials via interaction with their functional groups, mainly - $\mathrm{OH}$ groups [1]. Therefore, the combination between biopolymer and magnetic nanoparticles might result in the presence of more - $\mathrm{OH}$ groups which lead to higher adsorption capacity. Hence, it is straightforward that the As(III) treatment yield of biopolymer-based nanocomposites was highest due to the combined adsorption of biopolymer and well-dispersed magnetic nanoparticles. In addition, as mentioned previously, another importance role of magnetic nanoparticles in the composite is to easily collect the materials after treatment for reuse. 

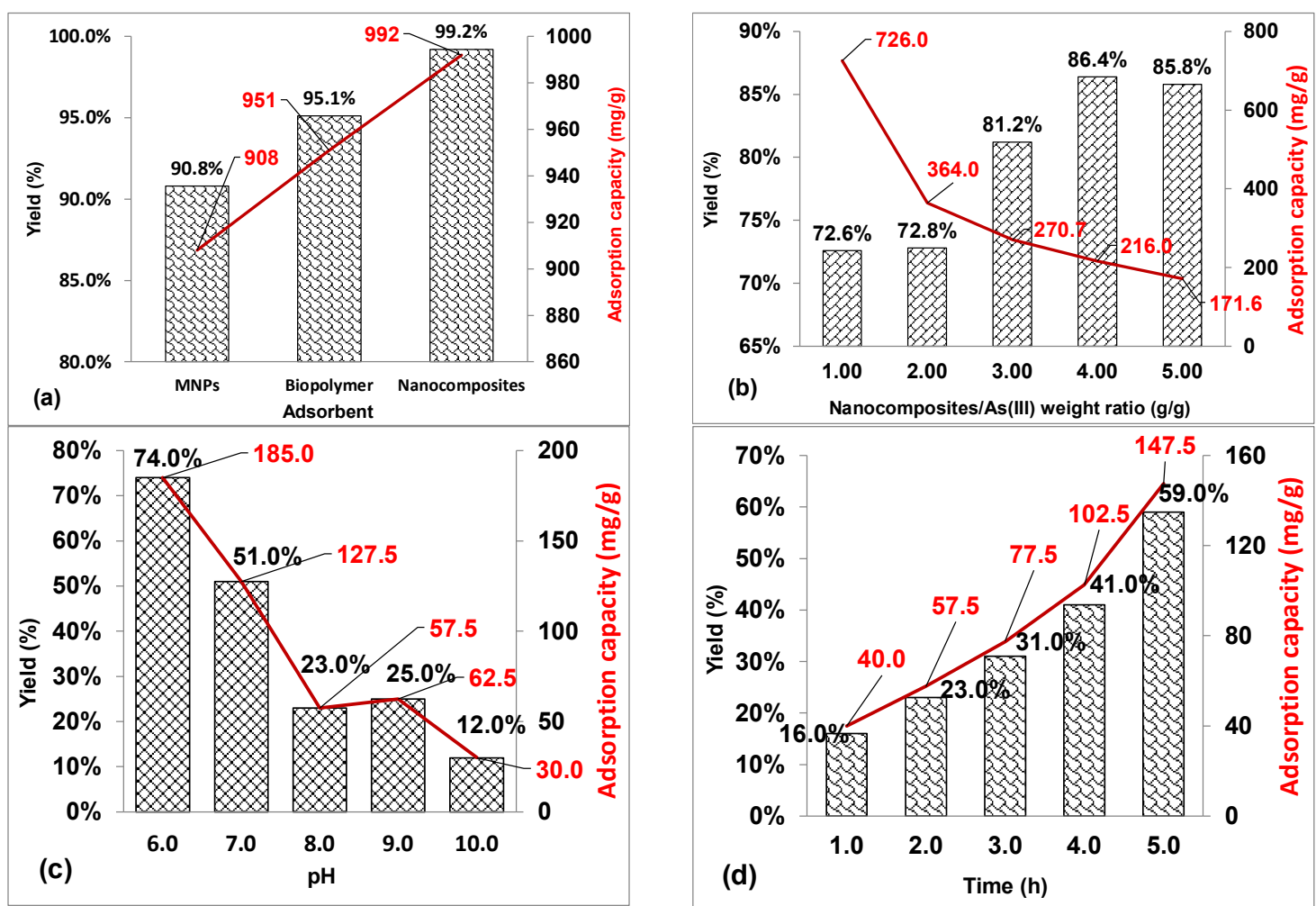

(b)
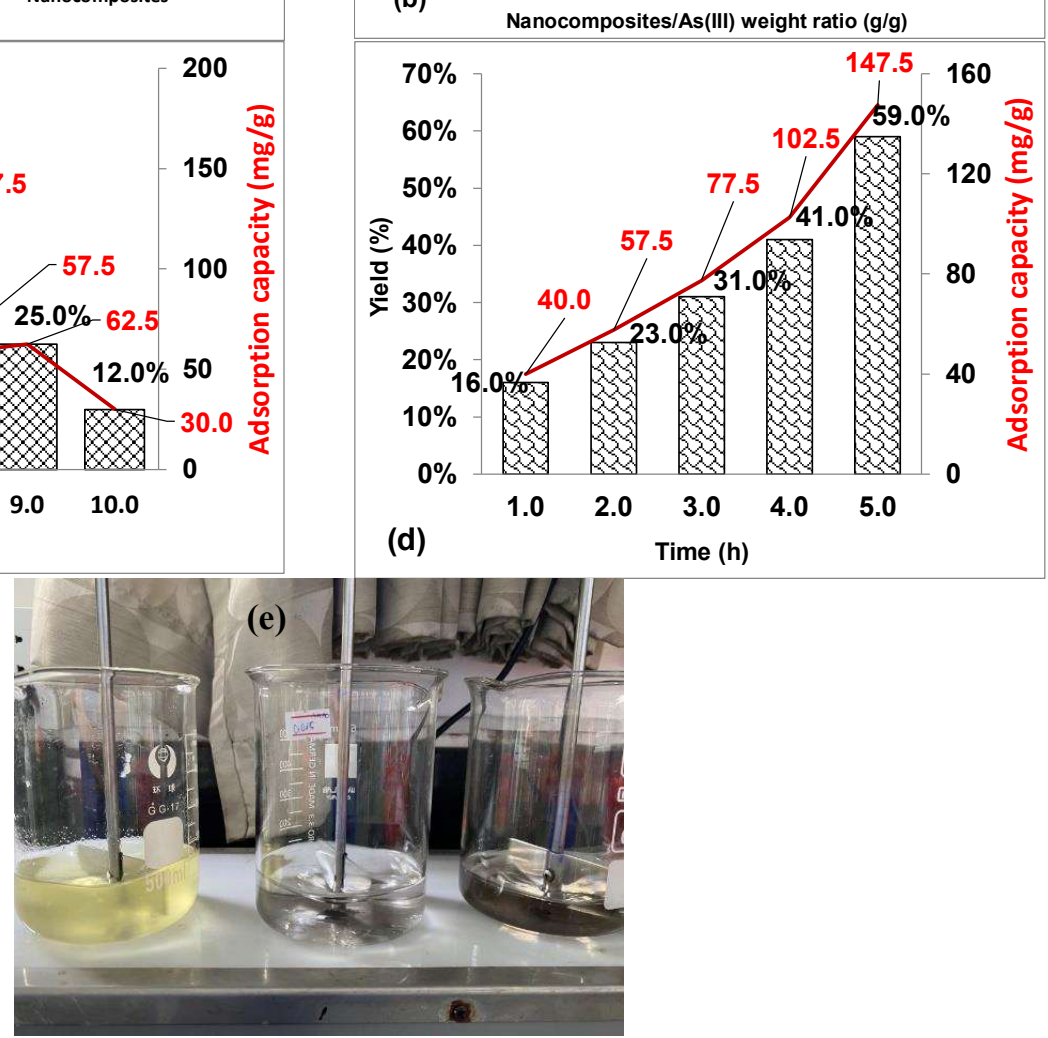

Figure 4. As(III) treatment efficiency: (a, e) Capability to treat As(III) of biopolymer, $-\mathrm{OH}$ enriched magnetic nanoparticles and nanocomposites; (b) Effect of nanocomposites/As(III) weight ratio; (c) Effect of pH; (d) Effect of contact time. Volume: $100 \mathrm{~mL}$; absorbent dose: $0.5 \div 2.5 \mathrm{~g} / \mathrm{L} ; \mathrm{pH}$ : $6-10$; room temperature; contact time: $1 \div 5 \mathrm{~h}$; agitation speed: $120 \mathrm{rpm}$

In addition, results showed that when increasing the concentration of nanocomposites adsorbent from 0.5 to $2.5 \mathrm{~g} / \mathrm{L}$, with a fixed dose of As(III) of $0.5 \mathrm{~g} / \mathrm{L}$, the highest efficiency of As(III) treatment was obtained when the mass ratio of nanocomposites adsorbent/As(III) reached 4/1, corresponding to used dose of nanocomposites adsorbent of $2.0 \mathrm{~g} / \mathrm{L}$ (Figure $4 \mathrm{~b}$ ). When the nanocomposites/As(III) mass ratio increased from 1.0 to 4.0 , the As(III) treatment efficiency increased from $72.6 \%$ to the highest value of $86.4 \%$. Usually, the As(III) treatment efficiency increased by increasing the dosage of the adsorbent. This is due to the increasing number of accessible active sites of the adsorbent for adsorption [29, 30]. Surprisingly, when increasing further the ratio to 5.0, the adsorption capacity slightly decreased. This could be attributed to the hindrance in approaching the adsorbent surface of the adsorbate if the density of the adsorbent is too high. It was also observed in this study that the Arsenic adsorption efficiency was highest, around $74 \%$, at $\mathrm{pH}$ 6.0. When $\mathrm{pH}$ solution increased to $10, \mathrm{As}(\mathrm{III})$ treatment efficiency dropped sharply to $12.0 \%$ (Figure 4c). This observation could be explained that the adsorption could not be performed at $\mathrm{pH}$ solution less than 6.0 because in acidic environment, Arsenic mainly exists in the form of neutral $\mathrm{H}_{3} \mathrm{AsO}_{3}$ reducing the ionic 
interaction with the adsorbent surface [30]. This result is consistent with the previous study which also used biopolymer based nanocomposites materials for arsenic removal [1]. Figure $4 \mathrm{~d}$ displays the effect of contact time on As(III) removal efficiency in which the efficiency increased almost linearly with the augmentation of the contact time.

The advantage of using magnetic nanocomposites materials is to be easily collected by magnets after usage (Fig 5a), then be reused for treating As(III) for subsequent times with similar conditions. Results of the recovery and probability of reusing nanocomposites materials were presented in Figure $5 \mathrm{~b}$, showing that after the fourth cycle, As(III) treatment efficiency was significantly reduced. This might be assigned to the incomplete elimination of $\mathrm{As}(\mathrm{III})$ forming the complex with the nanocomposites during the recovery process or could be due to the dispersion of part of the biopolymer into the wash water.

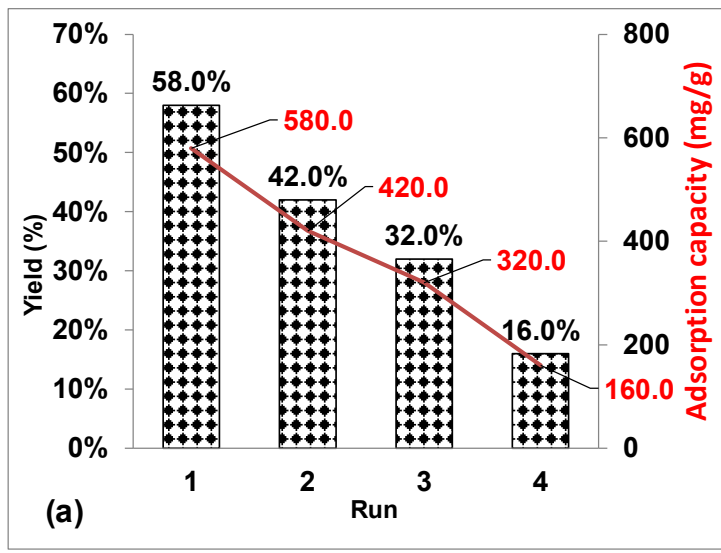

Figure 5. (a) Reusability of nanocomposites and (b) Treated sample after settling by magnet. Volume: $100 \mathrm{~mL}$; absorbent dose: $0.4 \mathrm{~g} / \mathrm{L}$; initial As(III) concentration $0.1 \mathrm{~g} / \mathrm{L} ; \mathrm{pH}$ 6; room temperature; contact time: $5 \mathrm{~h}$; agitation

\section{CONCLUSIONS}

speed: $120 \mathrm{rpm}$

In conclusion, successfully synthetic magnetic nanomaterials based on Orange peel biopolymer and magnetic $\mathrm{CoFe}_{2} \mathrm{O}_{4}$ nanoparticles were found to be capable of treating $\mathrm{As}(\mathrm{III})$ in aqueous solutions. It was also found that the treatment efficiency varied with factors including the nanocomposites/As(III) weight ratio, $\mathrm{pH}$, contact time. In fact, the $\mathrm{As}(\mathrm{III})$ adsorption was saturated at $0.4 \mathrm{~g} / \mathrm{L}$ nanocomposites when carrying out the treatment for $5 \mathrm{hrs}$ under stirring at $120 \mathrm{rpm}$. At the same time, with saturation magnetisation of $54.59 \mathrm{emu} / \mathrm{g}$ and magnetic resistance of $4940.06 \mathrm{G}$, the biopolymer nanocomposites are considered as soft and superparamagnetic material. These properties facilitate the nanocomposites to work at ambient temperature as well as to be easily recovered by an external magnetic field. In this study, the materials could be reused for 4 times. With all these findings, Orange peel biopolymer based magnetic nanocomposite is a potential sustainable adsorbent to treat As(III) in polluted water.

\section{REFERENCES}

[1] Muhammad Rahim and Mas Rosemal Hakim Mas Haris, "Application of biopolymer composites in arsenic removal from aqueous medium: A review Arsenic removal from aqueous medium using polymeric biocomposites," Journal of Radiation Research and Applied Sciences, vol. 43, pp. 255-263, 2015.

[2] M. Ashraf Ali et al., "Development of Low-cost Technologies for Removal of Arsenic from Groundwater," Technologies for Arsenic Removal from Drinking Water, pp. 99-120, 2001.

[3] Kailash Khulbe and T. Matsuura, "Removal of Heavy Metal Ions Using a Functionalized Single-Walled Carbon Nanotube: A Molecular Dynamics Study," Applied Water Science, vol. 8, p. 30, 2018.

[4] Dinesh Mohan and Charles U. Pittman, "Arsenic removal from water/wastewater using adsorbents-A critical review," Journal of Hazardous Materials, vol. 142, pp. 1-53, 2007. 
[5] A. S. Singha and A. Guleria, "Chemical modification of cellulosic biopolymer and its use in removal of heavy metal ions from wastewater," International Journal of Biological Macromolecules, vol. 67, pp. 409-417, 2014/06/01/ 2014.

[6] Rania E. Morsi et al., "Polythiophene modified chitosan/magnetite nanocomposites for heavy metals and selective mercury removal," Egyptian Journal of Petroleum, vol. 27, pp. 1077-1085, 2018.

[7] Ephraim Vunain et al., "Characterization and Application of Polymer Nanocomposites for Arsenic(III) Removal from Water," Journal of Inorganic and Organometallic Polymers and Materials, vol. 23, pp. 293305, 2013.

[8] Ammar Ahmad Khan et al., "Extraction and characterization of pectin from grapefruit (Duncan cultivar) and its utilization as gelling agent," International Food Research Journal, vol. 21, pp. 2195-2199, 2014.

[9] Nghia T. BUI et al., "Novel approach for collecting microalgae in water treatment using magnetic nanocomposites based on biopolymer extracted from grapefruit peel," Journal of Science and Technology vol. 39A, pp. 92-94, 2019.

[10] Mohamed S. A. Darwish et al., "Synthesis of Magnetic Ferrite Nanoparticles with High Hyperthermia Performance via a Controlled Co-Precipitation Method," Nanomaterials vol. 9, pp. 1176 - 1196, 2019.

[11] Enkuahone Abebe Alamineh, "Extraction of Pectin from Orange Peels and Characterizing Its Physical and Chemical Properties," American Journal of Applied Chemistry, vol. 6, pp. 51-56, 2018.

[12] Alok Kumar Tiwari et al., "Extraction and Characterization of Pectin from Orange Peels," International Journal of Biotechnology and Biochemistry, vol. 13, pp. 39-47, 2017.

[13] Prashansa P. Bagde et al., "Extraction of pectin from orange peel and lemon peel," International Journal of Engineering Technology Science and Research, vol. 4, pp. 1-7, 2017.

[14] Olugbenga Abiola Fakayode and Kingsley Emmanuel Abobi, "Optimization of oil and pectin extraction from orange (Citrus sinensis) peels: a response surface approach," Journal of Analytical Science and Technology, vol. 9, pp. 1-16, 2018.

[15] Adriana Cárdenas et al., "On the gelling behaviour of 'nopal' (Opuntia ficus indica) low methoxyl pectin," Carbohydrate Polymers, vol. 73, pp. 212-222, 2008.

[16] Francisco M. Goycoolea and Adriana Cárdenas, "Pectins from Opuntia spp.: A Short Review," Journal of the Professional Association for Cactus Development, vol. 5, pp. 17-29, 2003.

[17] B. Kazemzadeh et al., "Synthesis of a Novel Pectin-Based Superabsorbent Hydrogel with Salt and pHResponsiveness Properties," Biomed. \& Pharmacol. J., vol. 6, pp. 41 - 48, 2013.

[18] Zhenfa Zi et al., "Synthesis and magnetic properties of CoFe2O4 ferrite nanoparticles," Journal of Magnetism and Magnetic Materials, vol. 321, pp. 1251-1255, 2009.

[19] H. Iida et al., "Synthesis of $\mathrm{Fe}_{3} \mathrm{O}_{4}$ nanoparticles with various sizes and magnetic properties by controlled hydrolysis," Journal of Colloid and Interface Science, vol. 314, pp. 274-280, 2007.

[20] S. Sahu and R. K. Dutta, "Novel hybrid nanostructured materials of magnetite nanoparticles and pectin," Journal ofMagnetism and Magnetic Materials, vol. 323, pp. 980-987, 2011.

[21] J. Dai et al., "Facile synthesis of pectin coated $\mathrm{Fe}_{3} \mathrm{O}_{4}$ nanospheres by the sonochemical method," Journal of Magnetism and Magnetic Materials, vol. 331, pp. 62 - 66, 2013.

[22] Ji-Lai Gong et al., "Copper (II) removal by pectin-iron oxide magnetic nanocomposite adsorbent," Chemical Engineering Journal, vol. 185 - 186 pp. 100 - 107, 2012.

[23] D. Predoi et al., "Synthesis and characterization of bio-compatible maghemite nanoparticles," Digest Journal of Nanomaterials and Biostructures, vol. 5, pp. 779-786, 2010.

[24] Jude Namanga et al., "Synthesis and Magnetic Properties of a Superparamagnetic Nanocomposite "PectinMagnetite Nanocomposite"," Journal of Nanomaterials, p. 8, 2013.

[25] A. Rampino et al., "Chitosan-pectin hybrid nanoparticles prepared by coating and blending techniques," European Journal of Pharmaceutical Sciences, vol. 84, pp. 37-45, 2016.

[26] L. Guo et al., "Preparation and characterization of chitosan poly(acrylic acid) magnetic microspheres," Marine Drugs, vol. 8, pp. 2212-2222, 2010.

[27] K. S.Wilson et al., "A generalized method for magnetite nanoparticle steric stabilization utilizing block copolymers containing carboxylic acids," European Cells and Materials, vol. 3, pp. 206 - 209, 2002.

[28] CHANG Jing et al., "Fabrication of Poly $\left(\gamma\right.$-glutamic acid)-coated $\mathrm{Fe}_{3} \mathrm{O}_{4}$ Magnetic Nanoparticles and Their Application in Heavy Metal Removal," Chinese Journal of Chemical Engineering, vol. 21, p. 1244-1250, 2013.

[29] Jianghu Cui et al., "Oxidation and removal of AsIJIII) from soil using novel magnetic nanocomposite derived from biomass waste," Environmental Science Nanomaterials, vol. 6, pp. 478-488, 2019.

[30] Sahira Joshi et al., "Arsenic Removal fromWater by Adsorption onto Iron Oxide/Nano-Porous Carbon Magnetic Composite," Applied Sciences, vol. 9, p. 12, 2019. 


\section{XỬ LÝ As(III) TRONG NƯỚC BẰnG VẠTT LIỆU NANOCOMPOSITE TÙ TÍNH TRÊN NỀN POLYME SINH HỌC CHIẾT XUẤT TỬ VỎ CAM}

Tóm tắt. Nước ngầm nhiễm Arsen đang là vấn đề được quan tâm hiện nay bởi tác động của nó đến môi trường và sức khỏe con người. Nhiều phương pháp đã được sử dụng để xử lý vấn đề này. Trong nghiên cứu này, vật liệu nanocomposite từ tính được sử dụng để xử lý $\mathrm{As}(\mathrm{III})$. Vật liệu nanocomposite từ tính được chế tạo bằng cách kết hợp các hạt nano coban siêu thuận từ $\left(\mathrm{CoFe}_{2} \mathrm{O}_{4}\right)$ vào nền polyme sinh học được chiết xuất từ vỏ cam. Trong đó, các hạt nano từ tính được điều chế bằng phương pháp đồng kết tủa và sự hình thành nanocomposite được thực hiện với sự hỗ trợ của khuấy từ. Các phương pháp phân tích như: quang phổ hồng ngoại biến đổi Fourier (FT-IR), nhiễu xạ tia $\mathrm{X}(\mathrm{XRD})$, quét kính hiển vi điện tử (SEM) và từ kê mẫu rung (VSM) được sử dụng để kiểm tra đặc tính của vật liệu thu được. Vật liệu sau đó được sử dụng để xử lý As(III) trong nước sinh hoạt. Kết quả cho thấy, vật liệu nanocomposite có thể hấp phụ tới $99.2 \%$ As(III) (với nồng độ ban đầu của $\mathrm{As}(\mathrm{III})$ là $1.0 \mathrm{~g} / \mathrm{L}$, lượng vật liệu sử dụng $1.0 \mathrm{~g} / \mathrm{L}$ ). Sau quá trình xử lý, vật liệu nanocomposite dễ dàng được tách ra khỏi dung dịch bằng phương pháp gạn từ tính do đặc tính siêu thuận từ của vật liệu, quá trình xử lý và tái sử dụng vật liệu được thực hiện một cách thuận lợi.

Từ khóa. nanocomposite, từ tính, vỏ cam, polyme sinh học, siêu thuận từ, As(III), tái sử dụng.

Received on: $25 / 12 / 2020$

Accepted on: 29/03/2021 